\title{
The Effect of Cooperative Learning Models and Self Efficacy on Student Mathematics Learning Outcomes
}

\author{
Sabdo Puji Rahayu \\ Department of Education Technology \\ Postgraduate Program Universitas \\ Negeri Medan \\ Medan, Indonesia \\ sabdopujirahayu13@gmail.com
}

\author{
Mukhtar \\ Postgraduate Program Universitas \\ Negeri Medan \\ Medan, Indonesia
}

\author{
Keysar Panjaitan \\ Postgraduate Program Universitas \\ Negeri Medan \\ Medan, Indonesia
}

\begin{abstract}
This research aim to know: how students Mathematics learning outcomes whose taught using STAD learning model with TPS learning model, how students' Mathematics learning outcomes who have high self efficacy and low self efficacy, is there interaction between learning model and self efficacy to the students' Mathematics learning outcomes. The population consisted of 314 students in the $X$ MIPA grade of Medan 3 Senior High School in the second semester of 2017/2018 academic year and sample consisted of 74 students. The research method was quasi-experimental study using factorial $2 \times 2$ designs. The instrument used was Mathematics test which consist 35 multiple choices and instrument used was self efficacy which consist 30 questionnaire statements. The technique of data analysis using ANOVA two ways. The conclusion of the research are as follows: Students' Mathematics learning outcomes whose taught using STAD learning model is higher than with students' Mathematics learning outcomes taught using TPS learning model, Students' Mathematics learning outcomes who have high self efficacy is higher than low self efficacy, There is learning between the use of learning model and self efficacy on learning outcomes.
\end{abstract}

Keywords: Cooperative Learning Model, Learning Outcomes, Self Efficacy

\section{INTRODUCTION}

Education in schools is one very important path in order to improve the quality of Indonesian human resources. This was reinforced by the National Education System Law No. 20 of 2003 Chapter I general provisions of article I paragraph 1, stated that education is a conscious and planned effort to realize a learning atmosphere and learning process so that students actively develop their potential to have religious spiritual strength, self-control, personality, intelligence, noble character and the skills needed by him, the people of the nation and the state. One of the educational problems faced in Indonesia is the low quality of education in secondary schools.

The low quality of education in secondary schools, especially mathematics learning due to learning has not been meaningful for students. Learning will be meaningful for students if the teacher is able to generate students' motivation for the lesson. Student motivation will grow if the teacher implements concepts in students can give more meaning to him. In mathematics learning, many students who are less interested in mathematics are caused by inappropriate mathematical characteristics. Therefore, teachers need to understand the characteristics of mathematics learning.

Based on interviews with teachers of Medan 3 Senior High School that the basic mathematical abilities of students are still low, they often have difficulty in writing formulas that are appropriate to the problem, so that students also experience difficulties in communicating the completion process. In learning mathematics requires a good understanding of concepts, especially working on story problems in everyday life. This was supported by reports from the Third, which is currently the 2007 International Mathematics and Sciences Study Trends (TIMSS), Indonesia occupying 36 positions out of 49 countries.

In addition, it can also be seen in the implementation of the National Examination at the high school level of the Natural Sciences program in the last three years from TP 2012/2013 to 2014/2015 that the learning outcomes of mathematics at Medan 3 State Senior High School have not reached the Minimum Passing Criteria (KKM) which is 75 . This problem has been attempted to be overcome, but the results have not been significant.

The low learning achievement of mathematics requires changes in the learning process, one of which is the learning model. The use of learning models in presenting lessons is very influential on student learning outcomes. The use of the right learning model will overcome the saturation of students in receiving mathematics lessons.

One effort to improve student learning outcomes and the quality of education is by applying innovative learning models. With innovative learning, it is expected that mathematics learning is not boring, involving the active role of students, creating a pleasant atmosphere and the interaction between students in learning. Learning models that demand active students in group form are cooperative learning models. According to Slavin (Isjoni 2011: 17) that cooperative learning is a learning model that has been known for a long time, at 
which time the teacher encourages students to work together in certain activities such as discussion or teaching by peers (peer teaching). In carrying out the teaching and learning process the teacher no longer dominates as usual at this time, so students are required to share information with other students and learn from each other and their fellow students.

Student Teams Achievement Division (STAD) cooperative learning model is a cooperative learning model that emphasizes activities and interactions among students to motivate and help each other in mastering teacher learning material to achieve maximum results. According to Slavin (Trianto, 2014: 118) states that in the STAD model students are placed in a 4-5-member learning team which is a mixture according to level of achievement, gender, and ethnicity. The teacher presents lessons, and then students working on their team ensure that all team members have mastered the lesson. Then, all students were given tests about the material, during this test they were not allowed to help each other.

In addition, the cooperative learning model type Think Pair Share (TPS). According to Trianto (2014: 129) is a type of cooperative learning designed to influence student interaction patterns. This learning model is not just working in groups but this model consists of three processes. The first is Think, in this process students will individually understand a material delivered by the teacher. Then Pair, in this process students pair up to share information about the material delivered by the teacher. Then the last is the Share stage, in this process students in groups consisting of 4 people do a collaboration.

In addition, teachers in teaching and learning activities in class emphasize the cognitive domain so that other skills are less developed. Based on PP No. 54 of 2013, to achieve graduation competency standards, students must have 3 dimensions, namely the dimensions of attitude, knowledge, and skills. In addition to the dimensions of knowledge there are also other dimensions that can affect the success of student learning, namely the attitude dimension in the form of self efficacy.

Self efficacy is the belief in an individual's ability to determine and carry out various actions needed to produce an achievement. Alwisol (2009: 287) defines self efficacy as an assessment, whether it can perform good and bad actions, right or wrong, can or does not work as required. Efficacy is different from aspirations (ideals), because ideals describe something ideal that should be achieved, while efficacy describes self-assessment. Self efficacy has an important impact, even as the main motivator for one's success. By having self efficacy, someone will be more likely to do activities that he believes he can do rather than do work that they feel cannot be solved.

In the context of education, if students have self efficacy, they will be motivated to participate in learning activities so as to achieve learning goals and be able to survive when facing difficulties (assignments). According to Bandura (2008: 1) self efficacy will increase student success through two ways, namely, first, self-efficacy will foster an inner interest in activities that are considered attractive. Second, someone will manage themselves to achieve goals and be strongly committed.

But in reality, the importance of the role of self efficacy is not felt by some students. Sometimes students are considered that if they are smart they will always get good grades, and vice versa. In addition, when they will face challenges (tasks), some of them feel uncertain about their own abilities when facing the questions given by the teacher, they feel insecure if they have to compete with smarter friends, then they are not sure and not enthusiasm can work on increasingly difficult learning questions. Students tend to be shy and lack initiative to present their work because they are afraid of the wrong answers they say, they are not sure of the answers and the fear of getting bad grades if they are wrong in answering. The tendency to be ridiculed by classmates when one of the answers is also one of the causes.

In relation to the above, the purpose of this research is (1) to find out mathematics learning result student that is taught by Total Physical Response Method is higher than the result of learning English student which is taught by the Direct Method (2) to know the difference of mathematics learning result students who have visual learning style with English learning result of students who have auditory learning style (3) to know the interaction between learning method and student learning styles to English learning result.

\section{METHOD}

This research was conducted in Medan 3 State Senior High School having address at Jalan Budi Kemasyarakatan No. 54 in class $\mathrm{X}^{\text {th }}$ grade in the academic year $2017 / 2018$. The population in this study is all students of class $\mathrm{X}^{\text {th }}$ grade Medan. The sampling technique in this research is by cluster random sampling technique, class $X^{\text {th }}$ grade IPA 2 amounted to 36 students of the class given the learning with TPS Model and $\mathrm{X}^{\text {th }}$ grade IPA 8 amounted to 38 students of the class given the learning with STAD Model at Medan 3 State Senior High School.

The method used in this research is the experimental method (quasi experiment). The research design used is the factorial design $2 \times 2$.

TABLE I. Research Design

\begin{tabular}{|l|l|l|}
\hline \multirow{2}{*}{ Self Efficacy $(\mathrm{B})$} & \multicolumn{2}{|l|}{ Cooperative Learning Model $(\mathrm{A})$} \\
\cline { 2 - 3 } & $\mathrm{STAD}\left(\mathrm{A}_{1}\right)$ & $\mathrm{APS}_{1}\left(\mathrm{~A}_{2}\right)$ \\
\hline Hight $\left(\mathrm{B}_{1}\right)$ & $\mathrm{A}_{1}$ & $\mathrm{~A}_{2} \mathrm{~B}_{1}$ \\
\hline Low $\left(\mathrm{B}_{2}\right)$ & $\mathrm{B}_{2} \mathrm{~B}_{2}$ \\
\hline
\end{tabular}

Information:

A1B1 is the result of students' mathematics learning taught with STAD cooperative learning model for students who have high self efficacy

A1B2 is the result of students' mathematics learning taught by TPS cooperative learning model for students who have high self efficacy 
A2B1 is the result of students' mathematics learning taught with STAD cooperative learning model for students who have low self efficacy

A2B2 is the result of students' mathematics learning taught with TPS cooperative learning model for students who have low self efficacy

$=27.4)$. This shows that the STAD learning model is proven to be more effective in improving students' overall mathematics learning outcomes both for groups of students with high self efficacy and low self efficacy. From these findings, it is shown that to teach mathematics is more effective using the STAD learning model than the TPS learning model.

If further noted that in the STAD learning model the average mathematics learning outcomes of students with high self-efficacy $(X, 5=30.5)$ is better than the

\section{learning ou}

shows that self efficacy is significant enough to distinguish student learning outcomes, where student learning outcomes with high self efficacy both taught with STAD learning models and TPS learning models (learning outcomes with high and low self efficacy without seeing the learning model) are better than student learning outcomes with low self efficacy.

The results showed that all the research hypotheses were: (1) students' mathematics learning outcomes taught by the STAD learning model were higher than students' learning outcomes taught by the TPS learning model, (2) students' mathematics learning outcomes with high self efficacy were higher than the results students 'mathematics learning with low self efficacy, and (3) there is an interaction between learning models and self efficacy to influence the students' mathematics learning outcomes can be accepted by all three.

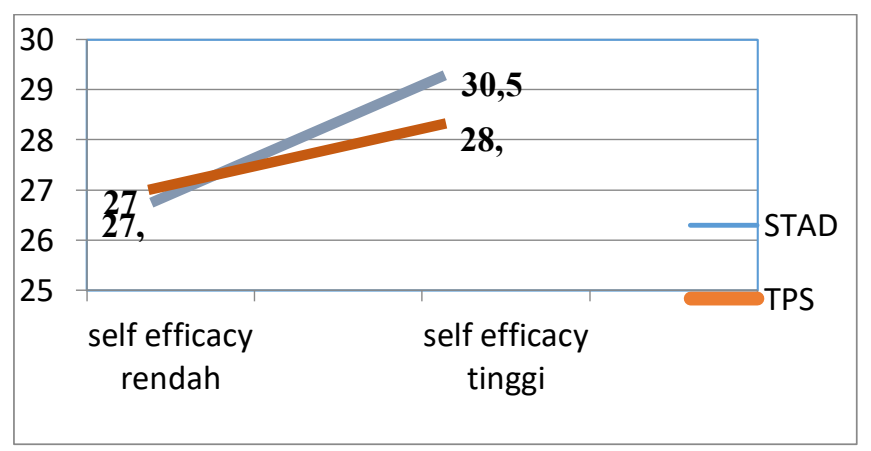

Fig 1. hypotheses of students' mathematics learning
The first hypothesis which states that mathematics learning outcomes between students taught with the STAD learning model gets an average score of 29.6 while the mathematics learning outcomes of students taught by the TPS learning model get an average score of 27.4. Students' mathematics learning outcomes that are taught by the STAD learning model are higher than the average scores of students who are taught by the TPS learning model. Which is strengthened by the results of the calculation of the Scheffe test. This shows that to teach mathematics lesson material it is better to use the STAD learning model compared to the TPS learning model. This is understandable because through the STAD learning model can encourage students to motivate and help each other in mastering the subject matter. Besides that the STAD learning model aims to instill mutual cooperation and help each other in solving problems, this mutual attitude is reflected in the learning process where in the STAD learning model students will compete with other students through the team. In the team, team members will try to help each other solve the problems presented, the mechanism for presenting material can be done with quizzes or presentation assignments. As stated by Gusniar (2013) states that learning models that are expected to foster collaboration, creative, critical thinking and the ability to help friends are STAD learning models.

The findings of this study are in line with the results of Wong's research, et al (2016) found that STAD cooperative learning techniques in mathematics learning can improve mathematics learning achievement. This study shows that STAD cooperative learning plays an important role as an active driver to improve mathematics learning achievement, then encourages students and teachers to be innovative and creative to improve teaching and learning mathematics in the classroom.

So it can be concluded that the use of the STAD learning model strongly encourages the improvement of mathematics learning outcomes and increases students' self-efficacy in independent learning in mathematics subjects.

The second hypothesis testing shows that students 'mathematics learning outcomes with high self efficacy are higher than students' mathematics learning outcomes with low self efficacy. This result proves that self efficacy is significant to distinguish mathematics learning outcomes. Self efficacy in this study is categorized as high self efficacy and low self efficacy. The results of the overall data analysis showed that the average mathematics learning outcomes of students with high self efficacy obtained an average score of 29.9 while the mathematics learning outcomes of students with low self efficacy obtained an average score of 27.2, so based on testing the second hypothesis it was proven that the low level of self efficacy has a significantly different effect on students' mathematics learning outcomes where Fcount $>$ Ftable, so that for the research hypothesis the two Ha are accepted and H0 is rejected. This indicates that students with high self efficacy on average have mathematics learning outcomes good compared to students with low self efficacy. Thus students with high self efficacy better understand and master the subject matter of mathematics compared to students with low self efficacy. 
From the third hypothesis testing there is an interaction between learning model and self efficacy in influencing students' mathematics learning outcomes. When viewed from the average learning outcomes of mathematics in the group of students with high self efficacy taught with STAD learning model is higher than the average learning outcomes of mathematics with a group of students with low self efficacy and taught with TPS learning models. Then the average of mathematics learning outcomes in the group of students with low self efficacy taught by the STAD learning model is lower than the average mathematics learning outcomes of students with low self efficacy who are taught by the TPS learning model. This means that for groups of students with high self efficacy it is better to use STAD learning models while students with low self efficacy are better taught using TPS learning models. This research is reinforced by previous research conducted by Yunianti, et al (2016) that there is an interaction between learning models and self efficacy towards students' mathematics learning outcomes.

Thus it can be concluded that the learning model and self efficacy significantly influence students' mathematics learning outcomes. Where students who have high self efficacy will tend to behave according to objects that can give high grades, therefore it can be said that students' mathematics learning outcomes are influenced by learning models and self efficacy, this shows that self efficacy factors are significant for differentiate student mathematics learning outcomes, where students 'mathematics learning outcomes with high self efficacy, both learned by applying STAD learning models and
TPS learning models are higher than students' mathematics learning outcomes with low self efficacy.

\section{CONCLUSION}

First, Students 'mathematics learning outcomes that are taught by STAD learning models are higher than students' mathematics learning outcomes that are taught by the TPS learning model.

Secondly, Mathematics learning outcomes of students who have high self-efficacy are higher than the mathematics learning outcomes of students who have low self-efficacy.

Third, There is an interaction between learning models and self efficacy towards students' mathematics learning outcomes. Students who have high self efficacy are more appropriately taught by using the STAD learning model while for students who have low self efficacy are more appropriately taught by using the TPS learning model.

\section{REFERENCES}

[1] S. Arikunto. 2013. Prosedur Penelitian Suatu Pendekatan. Jakarta: Rineka Cipta.

[2] Isjoni. 2009. Pembelajaran Kooperatif. Yogyakarta: Pustaka Pelajar.

[3] W. Santrock. 2007. Psikologi Pendidikan.Jakarta:Kencana Prenada Media Grup.

[4] Trianto. 2011. Mendesain Model Pembelajaran Inovatif-Progresif. Jakarta: Kencana.. 